\title{
Efek Pemberian Imunoterapi, Probiotik, Nigella sativa terhadap Th17, Neutrofil, dan Skoring Asma
}

\section{Effect of immunotherapy, Probiotic, Nigella sativa on Th17, Neutrophil, and Asthma Scoring}

\author{
Annisa Muhyi, Wisnu Barlianto, HMS Chandra Kusuma \\ Laboratorium Ilmu Kesehatan Anak Rumah Sakit Umum Daerah Dr. Saiful Anwar Malang
}

\begin{abstract}
ABSTRAK
Peran Th17 dalam patogenesis asma dan imunoterapi menjadi konsep dan paradigma terbaru. Imunoterapi merupakan salah satu manajemen di dalam asma dan memerlukan waktu yang lama sehingga sering mengakibatkan kegagalan terapi. Terapi adjuvant antara lain probiotik dan Nigella sativa diduga dapat meningkatkan efektifitas imunoterapi. Penelitian dilakukan untuk mengevaluasi efek pemberian imunoterapi, probiotik dan/atau Nigella sativa terhadap jumlah sel Th17, neutrofil dan skoring asma pada anak asma selama imunoterapi fase rumatan. Penelitian dilakukan pada 31 anak yang dikelompokkan secara acak yaitu imunoterapi plus plasebo atau imunoterapi plus Nigella sativa atau imunoterapi plus probiotik atau imunoterapi plus Nigella sativa plus probiotik selama 56 minggu. Pengukuran jumlah sel Th17 dan neutrofil dilakukan menggunakan flowcytometry setelah perlakuan. Asthma Control Test dilakukan untuk mengevaluasi gejala klinis. Data dianalisis menggunakan uji komparasi Anova One Way dan uji korelasi Pearson. Hasil menunjukkan tidak didapatkan perbedaan yang bermakna jumlah sel Th17 dan neutrophil antara kelompok perlakuan ( $p$-value 0,199 dan 0,326). Asthma control test secara bermakna didapatkan perbedaan antara perlakuan imunoterapi plus probiotik dibandingkan imunoterapi saja. Skoring asma pada kelompok perlakuan imunoterapi plus probiotik adalah yang tertinggi $(22,6)$. Jumlah sel Th17, neutrofil dan ACT menunjukkan hubungan yang lemah dan tidak bermakna secara statistik ( $r=-$ $0,2)(p=0,156)$. Jumlah sel Th17 dan neutrofil tidak didapatkan perbedaan yang bermakna. Skoring asma pada kelompok imunoterapi plus probiotik adalah yang tertinggi. Dapat disimpulkan tidak terdapat hubungan antara Th17, neutrofil dan skoring asma.
\end{abstract}

Kata Kunci: Imunoterapi, neutrofil, Nigella sativa, probiotik, sel Th17, skoring asma

\begin{abstract}
The role of Th17 cells in the pathogenesis of asthma and immunotherapy is being the latest concept and paradigm. Immunotherapy in asthma management requires long periods of time and often causes failure of therapy. Administration of adjuvans such as probiotics or Nigella sativa has been considered to improve its efficacy. This study was conducted To evaluate the effect of immunotherapy, probiotic or/and Nigella sativa adjuvant on th17 cells number, neutrophil count and asthma control test in asthmatic children in maintenance phase immunotherapy. A total of 31 children with asthma were enrolled and then randomized to receive immunotherapy plus placebo or immunotherapy plus Nigella sativa or immunotherapy plus probiotic or immunotherapy plus Nigella sativa plus probiotic for 56 weeks. The number of Th17 cells and neutrophil were measured by flowcytometry. Asthma control test was used to evaluate improvement of clinical symptoms. Anova One Way and Pearson correlation were used to analyze the results. The results show no significant difference on Th17 cells number and neutrophil count was not significantly different between treatment groups ( $p$-value 0,199 and 0,326). Asthma control test score were significantly different between immunotherapy alone and immunotherapy plus probiotic (p-value 0,017). Scoring asthma in group immunotherapy plus probiotic $(22,6)$ is the highest. The number of Th17 cells, neutrophil, and ACT score showed weak correlation and no significantly different (r=$0,2)(p=0,156)$. There is no difference of Th17 cells number and neutrophil between four groups. ACT of immunotherapy plus probiotic group has the highest score. There is no correlation between the number of Th17 cells, neutrophil count and ACT score in asthmatic children.
\end{abstract}

Keywords: Immunotherapy, neutrophil, Nigella sativa, probiotics, scoring asthma, Th17 cell

Jurnal Kedokteran Brawijaya, Vol. 28, No. 4, Agustus 2015; Korespondensi: Anisa Muhyi. Laboratorium Ilmu Kesehatan Anak Rumah Sakit Umum Daerah Dr. Saiful Anwar Malang, Jl. Jaksa Agung Suprapto 2 Malang. Telp (0341) 366242 Email:annisa_muhyi@yahoo.com 


\section{PENDAHULUAN}

Asma merupakan penyakit kronik pada anak yang paling banyak terjadi di dunia, dan merupakan salah satu penyebab kematian pada anak. Di Indonesia, dari berbagai penelitian di beberapa pusat pendidikan, prevalensi asma pada anak sekitar 2-16\% pada anak usia sekolah dasar. Asma merupakan penyakit saluran nafas dengan ciri terjadi inflamasi saluran nafas kronis, produksi mukus, hiperesponsif dan remodeling saluran nafas (1). Asma terjadi melalui mediasi oleh eosinofil, sel mast, sel Th2 dan Th17. Interleukin-17 yang diproduksi oleh Th17 akan terekspresi di saluran napas penderita asma. Peningkatan IL-17 memiliki korelasi dengan pengerahan neutrofil ke saluran napas (2).

Imunoterapi spesifik alergen merupakan salah satu metode dalam pengobatan asma. Pemberian imunoterapi pada anak asma dapat mempengaruhi keseimbangan aktivitas sel Th1, Th2, Th17, dan Treg. Prinsip mekanisme imunoterapi melalui induksi toleransi perifer sel $\mathrm{T}$ dan stimulasi sel Treg dapat mempengaruhi sel-sel T efektor baik Th1, Th2, dan Th17 (3). Pemberian adjuvant immunomodulator antara lain probiotik atau Nigella sativa saat ini sedang dilakukan penelitian untuk mengkontrol anak dengan asma. Probiotik adalah mikroorganisme saluran cerna komensal hidup yang jika diberikan dalam jumlah cukup akan bermanfaat untuk kesehatan manusia (4). Biji jinten hitam (Nigella sativa) digunakan dalam pengobatan tradisional untuk mengobati berbagai macam penyakit termasuk salah satunya adalah asma. Thymoquinone (TQ) yang terkandung pada biji Nigella sativa memiliki efek anti oksidan, anti inflamasi, anti histamin dan imunomodulator respon imun (5).

Keberhasilan pengobatan asma dinilai dengan keberhasilan kontrol asma. Tujuan tata laksana asma saat ini lebih menitikberatkan pada kontrol asma dan bukan lagi pada tata laksana serangan akut (6). Untuk mengevaluasi klinis asma digunakan skoring asma yaitu Asthma Control Test (ACT). Pemberian adjuvant probiotik atau Nigella sativa untuk meningkatkan modulasi sistem imun pada anak alergi yang telah mendapatkan immunoterapi masih kontroversial. Tujuan utama dari penelitian ini adalah mengetahui efek kombinasi imunoterapi fase rumatan, probiotik dan/atau Nigella sativa terhadap Th-17, neutrofil dan skoring asma. Selain itu, untuk mengetahui hubungan Th17, neutrofil dan skoring asma setelah mendapat kombinasi imunoterapi fase rumatan, probiotik dan/atau Nigella sativa.

\section{METODE}

Penelitian ini adalah penelitian eksperimental murni dengan rancangan penelitian randomized clinical trial (RCT) dan single blind. Subjek penelitian merupakan pasien rawat jalan Poli Alergi-Imunologi dan Respirologi Rumah Sakit Umum Saiful Anwar Malang. Kriteria inklusi adalah anak yang terdiagnosis asma berdasarkan pedoman nasional asma anak (PNAA) tahun 2012 untuk anak usia $\geq 5$ tahun dan indeks prediksi asma untuk anak $<5$ tahun. Derajat asma ringan yaitu intermiten dan persisten ringan berdasarkan global initiative for asthma (GINA) tahun 2014. Anak berusia 4-14 tahun dengan hasil skin prick test adalah alergi house dust mite (HDM) positif. Anak tersebut belum pernah mendapatkan imunoterapi. Orang tua bersedia secara sukarela mengikuti penelitian dan menandatangani informed consent. Kriteria eksklusi yang digunakan adalah pasien asma yang mengkonsumsi obat-obatan sitostastika. Pasien asma disertai dengan komorbid seperti otitis media, TBC, pneumonia dan polip hidung. Pasien yang menderita immunodefisiensi, penyakit autoimun, atau memiliki kelainan kardiovaskular dan memiliki riwayat alergi yang berat seperti syok anafilaksis dan asma serangan berat yang mengancam nyawa (life-threatening asthma). Pasien pernah menderita gagal napas atau pernah diintubasi dalam 1 tahun terakhir (7). Pasien yang menggunakan kortikosteroid inhaler dosis sedang, mengkonsumsi vitamin D3 dosis minimal 1200 IU/hari selama 3-4 bulan, mengkonsumsi $\beta$ blocker, penghambat angiotensin converting enzyme (ACE), antagonis leukotriene, teofillin, anti kolinergik, kromolin dan ketotifen secara rutin selama penelitian. Pasien mengalami eksaserbasi serangan asma atau infeksi saluran napas berat dalam 30 hari terakhir (8).

Subjek penelitian berjumlah 32 orang anak asma yang diambil secara consecutive sampling. Secara acak subjek dibagi menjadi 4 kelompok yaitu kelompok 1 mendapatkan imunoterapi dan placebo. Kelompok 2 mendapatkan imunoterapi dan Nigella sativa; kelompok 3 mendapatkan imunterapi dan probiotik; dan kelompok 4 mendapatkan imunoterapi dan Nigella sativa dan probiotik. Pada minggu ke-14 satu sampel kelompok imunoterapi dan Nigella sativa dan probiotik dinyatakan drop out karena tidak patuh mengkonsumsi Nigella sativa. Selama masa pengamatan tidak didapatkan efek samping dari perlakuan. Studi ini telah mendapatkan persetujuan dari komite etik Fakultas Kedokteran Universitas Brawijaya.

Klasifikasi asma pada penelitian ini adalah asma yang alergi terhadap HDM atau HDM disertai alergen yang lain (9). Asma ringan adalah asma alergi yang tergolong dalam intermitten asthma dan mild persistent asthma sesuai dengan klasifikasi GINA. Intermitten asthma ditandai dengan keluhan gejala harian $\leq 2$ hari/minggu dan tidak dikeluhkan gejala malam hari. Mild persistent asthma ditandai dengan keluhan yang muncul 2 kali/minggu dengan keluhan malam hari 1-2 kali/bulan (10).

Imunoterapi alergen HDM adalah pemberian berulang alergen (allergenic extract) HDM dengan dosis yang ditingkatkan secara bertahap untuk mendapatkan hiposensitisasi, yaitu untuk mengurangi gejala yang terjadi selama masih terpapar dengan alergen alami (11). Imunoterapi fase induksi diberikan subkutan HDM, konsentrasi 1:100 dengan dosis ditingkatkan setiap minggu sesuai protokol selama 14 minggu. Fase rumatan diberikan subkutan HDM, dosis 0,1 ml, konsentrasi 1:10, setiap 3 minggu selama 56 minggu.

Pemberian Nigella sativa diberikan selama imunoterapi fase rumatan yaitu 56 minggu dengan dosis $15 \mathrm{mg} / \mathrm{kg} /$ hari. Probiotik yang digunakan pada penelitian ini mengandung $2 \times 10^{9}$ cfu/gr Lactobacillus acidophilus $L A-5^{T M}$ dan Bifidobacterium lactis $B b-12^{T M}$, mix vitamin dan selenium yeast 1 ug yang diberikan selama 29 minggu dengan dosis 1 sachet per hari. Setelah diberikan perlakuan selama 56 minggu selanjutnya dilakukan pengukuran jumlah sel Th17 dan neutrofil serta perbaikan klinis melalui skoring asma ACT. Jumlah sel Th17 diambil dari peripheral blood mononuclear flowcytometry serta dianalisis software BD Cell Quest Pro dengan satuan persen (\%). Jumlah neutrofil diambil dari serum dianalisis dengan flowcytometry dengan melihat ekspresi $C D 4^{+} \mathrm{IL}-17$ satuan persen (\%). Skoring asma dinilai menggunakan skor ACT yaitu tes dengan mengisi kuisioner yang dikutip dari American Lung Association tahun 2002. Skor ACT $\geq 19$ diartikan asma terkontrol sedangkan < 19 diartikan asma tidak terkontrol. Data yang diperoleh dianalisis dengan uji komparasi Anova One Way untuk mengetahui perbedaan jumlah sel Th17 (CD4 $\left.{ }^{+} \mathrm{LL}-17\right)$, neutrofil dan skoring asma setelah perlakuan. 
Tabel 1. Karakteristik subjek penelitian

\begin{tabular}{|c|c|c|c|c|}
\hline Karakteristik subjek & $\begin{array}{l}\text { Imunoterapi } \\
\qquad(n=8)\end{array}$ & $\begin{array}{c}\text { Imunoterapi } \\
\text { dan } \\
\text { Nigella sativa } \\
\quad(n=8)\end{array}$ & $\begin{array}{c}\text { Imunoterapi } \\
\text { dan } \\
\text { Probiotik } \\
(n=8)\end{array}$ & $\begin{array}{c}\text { Imunoterapi } \\
\text { dan } \\
\text { Nigella sativa } \\
\text { dan probiotik } \\
(\mathrm{n}=7)\end{array}$ \\
\hline \multicolumn{5}{|l|}{ a. Usia (tahun) } \\
\hline$<5$ tahun & $1(1 / 8)$ & $1(1 / 8)$ & $1(1 / 8)$ & $0(0 / 7)$ \\
\hline$\geq 5$ tahun & $7(7 / 8)$ & $7(7 / 8)$ & $7(7 / 8)$ & $7(7 / 7)$ \\
\hline \multicolumn{5}{|l|}{ b. Jenis kelamin } \\
\hline -laki-laki & $5(5 / 8)$ & $2(2 / 8)$ & $4(4 / 8)$ & $4(4 / 7)$ \\
\hline -perempuan & $3(3 / 8)$ & $6(6 / 8)$ & $4(4 / 8)$ & $3(3 / 7)$ \\
\hline \multicolumn{5}{|l|}{ c. Riwayat atopi oraang tua } \\
\hline -tidak memiliki & $2(2 / 8)$ & $2(2 / 8)$ & $1(1 / 8)$ & $3(3 / 7)$ \\
\hline -memiliki & $6(6 / 8)$ & $6(6 / 8)$ & $7(7 / 8)$ & $4(4 / 7)$ \\
\hline \multicolumn{5}{|l|}{ d. Hasil skin prict test } \\
\hline -HMD & $3(3 / 8)$ & $4(4 / 8)$ & $2(2 / 8)$ & $1(1 / 7)$ \\
\hline$-\mathrm{HMD}+$ makanan & $3(3 / 8)$ & $2(2 / 8)$ & $4(4 / 8)$ & $5(5 / 7)$ \\
\hline -HMD + bulu kucing & $1(1 / 8)$ & $1(1 / 8)$ & $0(0 / 8)$ & $0(0 / 7)$ \\
\hline $\begin{array}{l}\text {-HMD + makanan + bulu kucing } \\
\text { e. Status gizi }\end{array}$ & & $1(1 / 7)$ \\
\hline -gizi baik & $8(8 / 8)$ & $6(6 / 8)$ & $7(7 / 8)$ & $7(7 / 7)$ \\
\hline -gizi kurang & $0(0 / 8)$ & $2(2 / 8)$ & $1(1 / 8)$ & $0(0 / 7)$ \\
\hline \multicolumn{5}{|l|}{ f. Diagnosis } \\
\hline -asma intermiten & $4(4 / 8)$ & $1(1 / 8)$ & $3(3 / 8)$ & $1(1 / 7)$ \\
\hline -asma persisten ringan & $4(4 / 8)$ & $7(7 / 8)$ & $5(5 / 8)$ & $6(6 / 7)$ \\
\hline
\end{tabular}

Apabila pada hasil skoring asma didapatkan hasil yang bermakna dilanjutkan ke Post Hoc Tukey Test.

\section{HASIL}

Penelitian mendapatkan 31 subjek penelitian yaitu 8 subjek mendapatkan imunoterapi dan placebo selama 56 minggu, 8 subjek mendapatkan imunoterapi dan Nigella sativa selama 56 minggu, 8 subjek yang mendapatkan imunoterapi selama 56 minggu dan probiotik selama 29 minggu awal pemberian imunoterapi dan 7 subjek yang mendapatkan imunoterapi dan Nigella sativa selama 56 minggu dan probiotik 29 minggu. Sebagian besar subjek penelitian berusia $>5$ tahun, status gizi baik, memiliki riwayat atopi orang tua, polisensitisasi terhadap alergen dan terdiagnosis asma persiten ringan (Tabel 1).

Perbandingan jumlah Th17 antar kelompok tercantum pada Gambar 1. Jumlah sel Th17 terendah terdapat pada kelompok kombinasi imunoterapi dan Nigella sativa dan probiotik. Perbedaan rerata jumlah sel Th17 tersebut secara statistik tidak berbeda bermakna (Gambar 1).

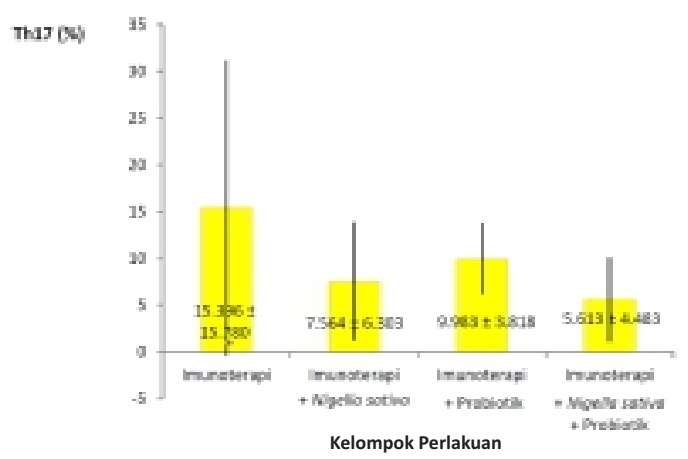

Gambar 1. Hasil perbandingan rerata jumlah \% sel Th17 setelah perlakuan
Perbandingan jumlah neutrofil antar kelompok tercantum pada (Gambar 2). Jumlah sel neutrofil terendah terdapat pada kelompok kombinasi imunoterapi dan Nigella sativa dan probiotik. Perbedaan rerata jumlah sel neutrofil tersebut secara statistik tidak berbeda bermakna (Gambar 2).

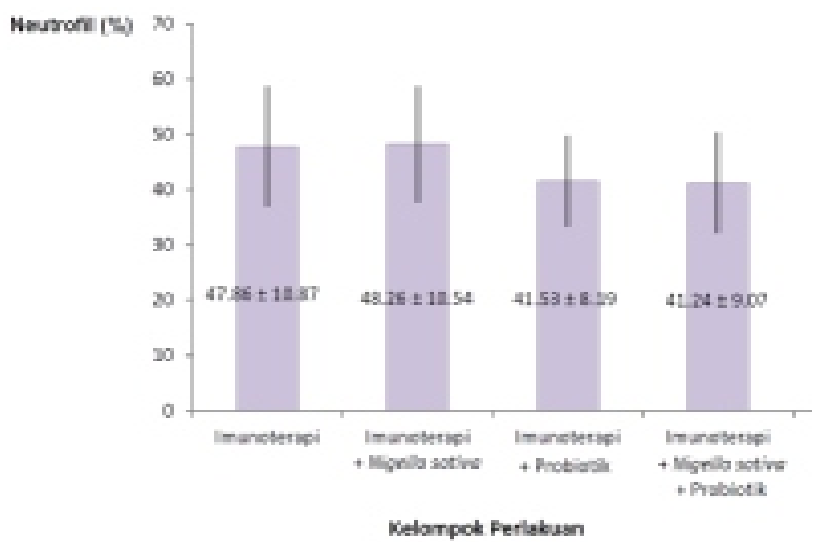

Gambar 2. Hasil perbandingan rerata jumlah \% neutrofil setelah perlakuan

Perbandingan skoring asma antar kelompok tercantum pada Gambar 3. Skoring asma tertinggi terdapat pada kelompok kombinasi imunoterapi dan probiotik. Perbedaan rerata skoring asma tersebut secara statistik berbeda bermakna. Perlakuan imunoterapi dan probiotik secara statistik bermakna memperbaiki skoring asma dibandingkan perlakuan imunoterapi saja (Gambar 3). 


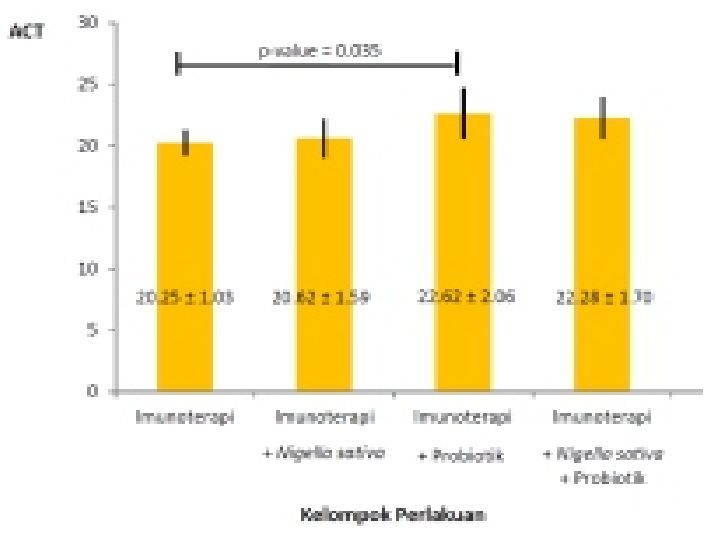

Gambar 3. Hasil perbandingan rerata jumlah skor ACT setelah perlakuan

Hubungan antara jumlah sel Th17 dan neutrofil dan skoring asma menunjukkan hubungan positif yang lemah dan tidak bermakna (Tabel 2). Hubungan antara Th17 dan neutrofil dengan skoring ACT menunjukkan hubungan negatifyang lemah dan tidak bermakna.

Tabel 2. Hasil uji korelasi jumlah sel Th17, neutrofil dan ACT setelah perlakuan

\begin{tabular}{lcc}
\hline \multicolumn{1}{c}{ Korelasi antara } & $\begin{array}{c}\text { Koefisien } \\
\text { korelasi }(\mathbf{r})\end{array}$ & p-value \\
\hline Th17 dan neutrofil & 0,133 & 0,477 \\
Th17 dan skoring ACT & $-0,261$ & 0,156 \\
Neutrofil dan ACT & $-0,264$ & 0,151 \\
\hline
\end{tabular}

Keterangan: Tidak terdapat hubungan antara Th17, neutrofil dan skoring asma

\section{DISKUSI}

Penelitian ini bertujuan untuk membuktikan pengaruh pemberian kombinasi imunoterapi spesifik HDM, probiotik (gabungan Lactobacillus acidophilus dan Bifidobacterium lactis) dan/atau Nigella sativa (jinten hitam) terhadap jumlah sel Th17 darah perifer, neutrofil dan skoring klinis pada anak asma ringan. Respon imun pada subjek dilihat dengan melihat profil sitokin yang dihasilkan oleh sel Th17 (CD4 ${ }^{+}$IL-17) dan neutrofil yang rendah setelah diberikan perlakuan selama fase rumatan. Penilaian perbaikan klinis setelah perlakuan menggunakan perhitungan skoring asma dengan ACT.

Imunoterapi adalah pemberian berulang dengan meningkatkan dosis alergen spesifik secara bertahap dengan tujuan memodulasi respon imun alergi sehingga gejala alergi menjadi lebih ringan (12). Pemberian imunoterapi akan memodulasi sistem imun sehingga lebih toleran terhadap alergen. Mekanisme modulasi sistem imun oleh imunoterapi melalui induksi sel Treg. Pemberian alergen secara bertahap akan menghasilkan sel dendrit matur yang lebih tolerogenik melalui stimulasi IL-1, IL-6, TLR 4 dan TLR 8. Sel dendrit matur yang tolerogenik akan menginisiasi diferensiasi sel CD4+ naive menjadi Treg. Selain itu, mekanisme toleransi terjadi karena penghambatan respon imun kearah Th2 melalui binding GATA3 secara langsung di region promoter FOXP3 sehingga ekspresi Th2 terhambat (13). Selain terjadi peningkatan ekspresi FOXP3, ekspresi sitokin IL-17 akan ditekan oleh TGF- $\beta$. Pemberian subkutan imunoterapi akan mengubah peran TGF- $\beta$ yang lebih cenderung menstimulasi sel T naïve menjadi Treg sehingga ekspresi Th17 akan tersupresi (12).

Pada penelitian ini, jumlah sel Th17 lebih rendah setelah pemberian kombinasi imunoterapi+Nigella sativa+probiotik dibandingkan kelompok perlakuan lainnya. Hasil ini menunjukkan bahwa Nigella sativa dan probiotik berguna sebagai terapi adjuvant selain pemberian imunoterapi saja. Penelitian oleh Soeharto tahun 2010 bahwa pemberian ekstrak Nigella sativa akan meningkatkan kadar TGF- $\beta$ pada cairan bronkoalveolar paru model mencit asma. Peningkatan TGF- $\beta$ akan meningkatkan ekspresi Treg dan mensupresi Th17 (12). Nigella sativa memiliki efek sebagai imunomodulator dan antioksidan pada dosis $5 \mathrm{mg} / \mathrm{kg} / \mathrm{hari}$ dengan menurunkan mediator inflamasi seperti IL-1 $\beta$, IL-6, TNF- $\alpha$, IFN- $\gamma$ dan IL10. Sel T efektor akan berdiferensiasi menjadi Th17 melalui stimulasi IL-6 dan IL-1 $\beta$. Penurunan mediator inflamasi IL-6 dan IL-1 $\beta$ akan menghambat diferensiasi sel Th17 (14).

Probiotik dapat memodulasi maturasi sel dendrit kemudian melepaskan IL-10 yang selanjutnya menstimulasi diferensiasi menjadi Treg. Mayoritas bakteri probiotik akan menginduksi diferensiasi Treg hanya Bifidobacterium bifidum yang dapat menginduksi aktivasi sel Th17 melalui pelepasan IL-17 (15). Bakteri probiotik yang digunakan pada penelitian ini adalah gabungan Lactobacillus acidophilus dan Bifidobacterium lactis Bb12. Modulasi sistem imun terhadap penyakit alergi oleh bakteri $L$. acidophilus dan $B$. Lactis adalah menghambat pelepasan IgE, IL-4, IL-5, IL-10, IL-6 dan IL-13, penurunan kadar CRP, meningkatkan regulasi TGF- $\beta$ dan meningkatkan Treg. Pelepasan IL-10 dan TGF- $\beta$ akan menghambat diferensiasi menjadi Th17 dan infiltrasi neutrophil (16).

Bakteri probiotik L. acidophilus dan B. Lactis digunakan sebagai terapi terhadap penyakit alergi. Penggunaan probiotik untuk terapi asma pada anak masih sedikit dillakukan. Pemberian probiotik selama 16 minggu secara signifikan dapat memperbaiki dermatitis atopi dari nilai perbaikan scoring atopic dermatitis (SCORAD) (15). Studi terhadap anak dengan mengi berulang dan riwayat atopi keluarga tidak memberikan efek positif terhadap asma dan dermatitis atopi hanya efek ringan terhadap sensitisasi alergi setelah pemakaian probiotik selama 6 bulan. Studi terbaru pada model mencit asma yang diberikan peroral $\mathrm{L}$. gasseri akan meringankan inflamasi saluran nafas dan menginduksi penurunan respon imun yang dimediasi oleh IL-17. Efek pemberian probiotik terhadap pencegahan dan pengobatan penyakit alergi tergantung dari strain bakteri probiotik, lama penggunaan dan dosis yang digunakan. Studi efikasi pemberian probiotik hanya terbukti pada penyakit dermatitis atopi tetapi belum memberikan efek yang bermanfaat pada alergi makanan dan asma (17).

Tanabe tahun 2013 menyatakan mikrobiota saluran cerna dan probiotik akan mengadakan homeostasis. Jika probiotik diberikan dengan dosis, durasi pemberian, jenis strain yang tidak tepat juga dapat mengakibatkan produksi IL-17 yang berlebihan. Interleukin 17 merupakan sitokin proinflamasi jika keberadaan Th17 yang cukup dapat memberikan keuntungan bagi penjamu sebagai 
mekanisme pertahan tubuh terhadap bakteri dan jamur. Kondisi yang tidak menguntungkan jika terjadi overproduksi IL17 (18).

Pada penelitian sebelumnya disebutkan bahwa jumlah sel Th17 juga berhubungan dengan derajat beratnya asma. Pada pasien asma berat ditemukan peningkatan jumlah sel Th17 pada saluran napas mereka yang berkorelasi dengan peningkatan infiltrasi neutrofil, produksi kemokin IL-8, dan derajat hiperresponsif saluran napas (19). Belum ada penelitian yang membandingkan jumlah sel Th17 pada asma ringan (antara asma intermiten dan persisten ringan), tetapi dari definisinya asma persisten lebih berat dibandingkan asma intermiten dan durasi sakitnya juga lebih lama, sehingga jumlah sel Th17 akan lebih tinggi pada asma persisten daripada intermiten.

Meskipun secara statistik tidak didapatkan nilai yang signifikan, tetapi nilai-nilai diatas tetap harus diperhatikan, bahwa pada pasien-pasien yang menderita asma persisten dengan hasil skin prick test didapatkan polialergen selain HDM, akan mengalami peningkatan jumlah sel Th17. Sel Th17 akan menghasilkan IL-17 yang menginduksi fibroblas bronkus yang meningkatkan ekspresi beberapa mediator-mediator lain seperti IL-6, GM-CSF, CXCL8 dan PGE2 yang berperan pada inflamasi lokal saluran napas dan menyebabkan airway remodeling. Proses airway remodeling ini menyebabkan penebalan dinding saluran napas, fibrosis subepitel, hipertrofi dan hiperplasi saluran napas dan proses angiogenesis yang berimplikasi mudah terjadi obstruksi saluran napas dan timbulnya serangan asma yang akut pada pasien $(19,20)$. Oleh karena itu, pasien dengan asma persisten memerlukan pertimbangan untuk pemberian adjuvant probiotik dan Nigella sativa agar asma bisa terkontrol dengan baik dan proses airway remodeling bisa dihambat sejak awal.

Asthma control test adalah salah satu metode menilai klinis asma dalam bentuk skoring numerik. Dari hasil penelitian didapatkan bahwa terdapat perbedaan skoring asma yang bermakna antara kelompok penelitian. Rerata jumlah skoring terendah adalah kelompok perlakuan imunoterapi yaitu 20,250 $\pm 1,035$ sedangkan rerata jumlah skoring tertinggi adalah kelompok perlakuan imunoterapi dan probiotik. Pemberian probiotik memberikan efek yang positif dalam penelitian ini. Probiotik yang dikombinasikan dengan pemberian imunoterapi dapat menstimulasi maturasi sel dendritik dan meningkatkan kadar IL-10 yang mempunyai efek anti inflamasi dan menginduksi aktivitas sel Treg sehingga dapat menekan gejala klinis reaksi alergi (21). Penelitian Kim et al strain bakteri probiotik Lactobacillus acidophilus dan Bifidobacterium lactis dapat meningkatkan keseimbangan Th1/Th2 melalui peningkatan produksi IL-10 dan TGF- $\beta$ serta penurunan IL-4 dan IgE (16).

Efek terapi probiotik terhadap asma adalah mensupresi inflamasi saluran napas yang berkaitan dengan alergi. Pemberian Lactobacillus akan mengurangi hiperplasia sel goblet secara signifikan. Selain itu probiotik Bifidobacterium akan mensupresi fenotip asma, reaktivasi saluran napas, produksi eosinofil dan IgE. Studi terbaru mengenai efektifitas probiotik terhadap anak asma adalah mencegah eksaserbasi (21). Pemberian probiotik Lactobacillus selama 8 minggu setiap hari pada penderita anak asma secara signifikan dapat memperbaiki fungsi saluran napas, gejala klinis, dan produksi sitokin untuk regulasi sistem imun dibandingkan dengan grup control (22). Hasil penelitian tersebut merupakan pembuktian bahwa probiotik berfungsi sebagai imunomodulator sehingga klinis asma membaik.

Pemberian imunoterapi saja ternyata tidak memberikan hasil ACT yang memuaskan dibandingkan pemberian adjuvant probiotik atau kombinasi dengan probiotik dan Nigella sativa. Imunoterapi HDM tidak dapat memberikan pencegahan terhadap perkembangan sensitisasi alergen lainyang baru pada subjek monosensitisasi HDM. Imunoterapi dapat meringankan gejala asma, mengurangi penggunaan obat-obatan asma dan penurunan hiperreaktivitas bronkus. Imunoterapi dapat menurunkan konsentrasi eosinofil, neutrofil dan endotelin-1 sebagai bronkokonstriktor dan proinflamasi setelah pemberian imunoterapi HDM selama 2 tahun. Imunoterapi dapat bertahan untuk meregulasi sistem imun selama 3-4 tahun setelah pemberhentian imunoterapi (13).

Skoring asma nomor dua terbaik setelah kelompok imunoterapi dan probiotik adalah kelompok pemberian kombinasi imunoterapi + probiotik + Nigella sativa. Minyak biji Nigella sativa dapat menurunkan derajat inflamasi saluran napas sebanding dengan antihistamin generasi ke2 pada mencit model asma. Nigella sativa dapat meningkatkan jumlah limfosit $\mathrm{TCD} 4^{+} \mathrm{CD} 25^{+} \mathrm{FoxP}^{+}$dan sel limfosit T $\mathrm{CD}^{+}$serta menurunkan jumlah sel limfosit T CD4 ${ }^{+}$ (23). Penelitian oleh Aziz MA tahun 2014 pada model mencit asma alergi yang diberikan minyak Nigella sativa terjadi penurunan secara bermakna jumlah eosinofil. Pada penelitian ini juga terbukti bahwa Nigella sativa terbukti sebagai imunomodulator dan antiinflamasi sehingga berguna untuk pengobatan asma alergi (24).

Hasil uji statistik menyatakan tidak terdapat hubungan jumlah sel Th17, neutrofil dan skoring klinis asma setelah pemberian imunoterapi, imunoterapi + probiotik, imunoterapi + Nigella sativa dan imunoterapi + probiotik + Nigella sativa. Hasil ini tidak sesuai dengan penelitian yang telah ada yang menyatakan penurunan Th17 akan diikuti dengan peningkatan apoptosis neutrofil sehingga klinis asma akan membaik. Peningkatan konsentrasi IL-17 akan memperlambat apoptosis neutrofil dan meningkatkan kemotaksis IL-8 yang berfungsi untuk migrasi neutrofil di saluran napas. Pada penelitian ini jumlah sel Th17 yang menurun tidak diikuti dengan penurunan neutrofil. Banyak faktor yang mempengaruhi sintesis dan infiltrasi neutrofil sehingga bukan hanya melihat dari jumlah CD4+IL-17 tetapi IL-8, jenis alergen HDM dan kondisi individu akan mempengaruhi konsentrasi neutrofil dalam serum (25). Kelemahan pada penelitian ini adalah IL-8 dan jenis HDM tidak diukur dan tidak dapat diidentifikasi sehingga kemungkinan hal tersebut yang mengakibatkan hasil penelitian tidak berhubungan.

Beberapa kendala yang dihadapi dan menjadi kelemahan pada penelitian ini adalah tidak diketahuinya faktor lain yang dapat menjadi variabel bebas yaitu etiologi jenis HDM dan IL-8 yang mempengaruhi Th17 (25). Pada penelitian ini didapatkan jumlah sel Th17 dan neutrofil turun pada kelompok kombinasi imunoterapi dan probiotik dan Nigella sativa akan tetapi peneliti tidak dapat menyatakan terjadi penurunan setelah perlakuan karena tidak dilakukan pengukuran sebelum perlakuan. Jumlah sel Th17 dan neutrofil yang turun tersebut tidak dapat dikatakan lebih baik dan turun setelah perlakuan kombinasi imunoterapi dan probiotik dan Nigella sativa 
karena tidak memiliki data kelompok kontrol negatif jumlah sel Th17 dan neutrofil pada anak yang sehat. Kelemahan pada penelitian ini adalah waktu pengamatan yang kurang lama karena efektifitas imunoterapi akan tercapai setelah pemberian 3 tahun. Waktu pengamatan yang terbatas ini adalah salah satu kemungkinan yang mengakibatkan jumlah sel Th17 turun secara tidak bermakna.

Kesimpulan dari penelitian ini adalah kombinasi

\section{DAFTAR PUSTAKA}

1. Sundaru H. House Dust Mite Allergen Level and Allergen Sensitization as Risk Factors for Asthma among Student in Central Jakarta. Medical Journal of Indonesia. 2006;15(1): 55-59.

2. Park SJ and Lee YC. Interleukin-17 Regulation: An Attractive Therapeutic Approach for Asthma. Respiratory Research. 2010; 11(1): 11.

3. Fujita $H$, Soyka MB, Akdis $M$, and Akdis CA. Mechanisms of Allergen-Specific Immunotherapy. Clinical and Translational Allergy. 2012; 2: 1-8.

4. Bodera $\mathrm{P}$ and Chcialowski A. Immunomodulatory Effect of Probiotic Bacteria. Recent Patents on Inflammation \& Allergy Drug Discovery. 2009; 3(1): 58-64.

5. Paarakh PM. Nigella sativa Linn.-A Comprehensive Review. Indian Journal of Natural Products and Resources. 2010; 1(4): 409-429.

6. Bateman ED, Hurd SS, Barnes PJ, et al. Global Strategy for Asthma Management and Prevention: GINA Executive Summary. Europe Respiratory Journal. 2008; 31(1): 143-178.

7. Divatia JV and Bhowmick K. Complications of Endotracheal Intubation and Other Airway Management Procedure. Indian Journal of Anaesthesia. 2005;49(4): 308-318.

8. Gupta A, Bush A, Hawrylowi C, and Saglani S. Vitamin $D$ and Asthma In Children. Paediatric Respiratory Review 2012; 13(14): 236-243.

9. Supriyatno B, Wahyudin B. Patogenesis dan Patofisiologi Asma Anak. Di dalam: Rahayu NN, Supriyatno B, Setyanto DB (Eds). Buku Ajar Respirologi Anak. Jakarta: Badan Penerbit IDAl; 2010: hal. 85-98.

10. GINA. Global Strategy For Asthma Management And Prevention; 2014.

11. Cox L, Nelson H, Lockey $\mathrm{R}$, et al. Allergen Immunotherapy: A Practice Parameter Third Update. Journal of Allergy and Clinical Immunology. 2010; 127(1): S 1-S55.

12. Cappella A and Durham SR. Allergen Immunotherapy for Allergic Respiratory Diseases. Human Vaccines \& Immunotherapeutics. 2012; 8(10): 1499-1512.

13. Akdis $M$ and Akdis CA. Mechanisms of AllergenSpecific Immunotherapy: Multiple Suppressor Factors at Work in Immune Tolerance to Allergens. The Journal of Allergy Clinical Immunology. 2014; 133(3): 621-631. imunoterapi, probiotik dan/atau Nigella sativa tidak memberikan efek yang positif terhadap sel Th17 dan neutrofil. Pemberian probiotik terhadap anak asma yang mendapatkan imunoterapi memberikan manfaat yaitu perbaikan skoring asma setelah perlakuan. Hubungan antara jumlah sel Th17, neutrofil dan skoring klinis pada anak asma ringan yang mendapatkan kombinasi imunoterapi fase rumatan, probiotik dan/atau Nigella sativa belum terbukti.

14. Ahmad A, Husain A, Mujeeb $M$, et al. A Review on Therapeutic Potential of Nigella sativa: A Miracle Herb. Asian Pacific Journal of Tropical Biomedicine. 2013; 3(5): 337-352.

15. Toh ZQ, Anzela A, Tang ML, and Licciardi PV. Probiotic Therapy as A Novel Approach for Allergic Disease. Frontiers in Pharmacology. 2012; 3: 171-183.

16. Kim JM, Lin SY, Suarez-Cuervo C, et al. Allergen-Specific Immunotherapy for Pediatric Asthma and Rhinoconjunctivitis: A Systematic Review. Pediatrics. 2013; 131(6): 1155-1167.

17. Castellazzi AM, Valsecchi C, Caimmi S, et al. Probiotic and Food Allergy. Italian Journal of Pediatrics. 2013; 39: 1-10.

18. Tanabe S. The Effect of Probiotics and Gut Microbiota on Th17 Cells. International Review of Immunology. 2013; 32(5-6): 511-525.

19. Heialy SA, Mcgovern TK, and Martin JG. Insights Into Asthmatic Airway Remodelling Through Murine Models. Respirology. 2011; 16(4): 589-597.

20. Baraldo S, Turato G, Bazzan E, et al. Noneosinophilic Asthma in Children: Relation with Airway Remodelling. Europe Respiratory Journal. 2011; 38(3): 575-583.

21. Ozdemir O. Various Effects of Different Probiotic Strains in Allergic Disorders: An Update From Laboratory and Clinical Data. Clinical and Experimental Immunology. 2010; 160(3): 295-304.

22. Chen $Y S$, Jan RL, Lin $Y L$, Chen $H H$, and Wang JY. Randomized Placebo-Controlled Trial of Lactobacillus on Asthmatic Children with Allergic Rhinitis. Pediatrics Pulmonoloy. 2010; 45(11): 1111-1120.

23. Kusuma M, Barlianto W, Widodo A, and Suharto S. Crude Extract of Black Seed (Nigella sativa) can Modulate TCD4+ and CD8+ Lymphocytes in Asthmatic Mouse Model. Paediatric Respiratory Reviews. 2012; 13(11): S55.

24. Abdel-Aziz M, Abass A, Zalata K, Abd Al-Galel T, Allam $\mathrm{U}$, and Karrouf G. Effect of Dexamethasone and Nigella sativa on Inducible Nitric Oxide Synthase in the Lungs of a Murine Model of Allergic Asthma. Iranian Journal of Allergy, Asthma, and Immunology. 2014; 13(15): 324-334.

25. Bajoriūnienè I, Malakauskas K, Lavinskienè S, et al. Peripheral Blood Th17 Cells and Neutrophils in Dermatophagoides Pteronyssinus-Induced Early-and Late-Phase Asthmatic Response. Medicine (Kaunas). 2012; 48(9): 442-451. 